\title{
PEMBATASAN TERHADAP HAK DAN KEBEBASAN BERAGAMA DI INDONESIA
}

\author{
Muwaffiq Jufri \\ Program Studi Ilmu Hukum Universitas Brawijaya \\ Jl. MT. Haryono No. 169 Malang \\ email: muwaffiq.jufri@gmail.com
}

\begin{abstract}
As one of modern law state, Indonesia provides arrangement and guarantee of human rights and freedom of religion. Moreover, this guarantee is clearly stated in the Constitution of the Republic of Indonesia Year 1945. It indicates the existence of human rights and freedom of religion is a constitutional right. Nevertheless, the limitations existed on freedom of religion set out in some legislations affect negatively due to unclear concept of those arrangements. It is became worsen when the limitations of provisions are actually used to justify the action of radicalism in the name of religion. Therefore, scientific studies about the conception of limitations on freedom of religion become urgent as a preventive step in order to avoid the misuse of provisions limitations in the freedom of religion.
\end{abstract}

Keyword: human rights, freedom, religion, and limitations.

\begin{abstract}
Abstrak: Sebagaimana lazimnya negara hukum modern, Indonesia memberikan pengaturan serta jaminan terhadap hak dan kebebasan beragama. Bahkan jaminan ini secara jelas dicantumkan dalam Undang-Undang Dasar Negara Republik Indonesia Tahun 1945. Ini menandakan bahwa keberadaan hak dan kebebasan beragama merupakan hak yang konstitusional. Meski demikian, keberadaan pembatasan terhadap kebebasan beragama yang diatur dalam beberapa peraturan perundangundangan, memberikan dampak negatif karena ketidakjelasan konsep pengaturannya. Parahnya, ketentuan pembatasan tersebut justru dijadikan alasan pembenar dalam melakukan aksi radikalisme atas nama agama. Untuk itu, kajian ilmiah mengenai konsepsi pembatasan terhadap kebebasan beragama menjadi urgen sebagai langkah antisipasi agar ketentuan pembatasan kebebasan beragama tidak disalahfungsikan.
\end{abstract}

Kata Kunci: hak, kebebasan, agama, dan pembatasan.

Berdasarkan ketentuan Pasal 1 ayat (3) UndangUndang Dasar Negara Republik Indonesia Tahun 1945 (UUD NRI 1945) yang menegaskan bahwa negara Indonesia didasarkan pada hukum. Ketentuan tersebut berimplikasipada segala tindakan yang dilakukan dalam rangka menjalankan roda organisasi negara harus didasarkan pada ketentuan hukum yang berlaku. Terkait dengan negara hukum, R. Soepomo seperti yang dikutip oleh Fadjar (2004:7) mengemukakan pandangannya bahwa Negara hukum ialah Negara yang tunduk pada hukum, peraturan-peraturan hukum berlaku bagi segala badan dan alat-alat perlengkapan Negara. Negara hukum juga akan menjamin tertib hukum dalam masyarakat yang artinya memberikan perlindungan hukum, serta terjadi hubungan timbalbalik antara hukum dan kekuasaan.
Aspek negara hukum dalam perkembangannya tidak hanya terfokus pada masalah peraturan dan tertib hukum, tetapi juga pada upaya perlindungan terhadap prinsip-prinsip hak asasi manusia (HAM). Negara hukum modern menghendaki perlindungan dan penegakan terhadap HAM. Seperti yang disampaikan oleh Van Wijk yang dikutip oleh Attamimi (2014:18) bahwa Negara hukum (rechtsstaat) memiliki unsur-unsur sebagai berikut: (1) Pemerintahan menurut hukum (vetmatig besture), dengan bagian-bagiannya tentang kewenangan yang dinyatakan dengan tegas, tentang perlakuan yang sama, dan kepastian hukum; (2) Jaminan atas hakhak asasi; dan (3) Pembagian kekuasaan dengan bagian-bagiannya tentang struktur kewenangan 
atau desentralisasi dan tentang pengawasan dan kontrol. Dengan demikian, jaminan atas hak asasi manusia menjadi hal yang wajib pemenuhannya dalam suatu negara yang berlandaskan hukum.

Sebagai negara hukum modern, Indonesia telah memberikan aturan mengenai perlindungan terhadap prinsip-prinsip HAM, ini bisa dibuktikan dengan adanya ketentuan pasal 28a hingga Pasal 28j UUD NRI 1945 yang khusus membahas tentang HAM. Tentu keberadaan pasal-pasal tersebut menjadi "angin segar" dalam upaya melindungi kepentingan rakyat dari tindakantindakan yang berpotensi merenggut hak asasi yang seharusnya mereka miliki.

Menariknya, ketentuan kebebasan beragama mendapatkan posisi terhormat dalam UUD NRI 1945. Kebebasan beragama secara jelas dinyatakan dalam ketentuan pasal 28E Ayat (2) yang berbunyi "bahwa setiap orang bebas memeluk agama dan beribadah menurut agamanya". Menurut Fahmi (2011:57), kata "setiap orang" berarti "semua orang", tidak membedakan ras, suku, warga negara mana, dan latar belakang primordial lainnya. Dengan demikian, pasal ini memang ditujukan untuk melindungi hak asasi manusia yang paling asasi, berlaku universal dan lintas batas teritorial, adat, budaya, dan perbedaan sosial-politik lainnya.

Selain itu, Pasal 28E ayat (2) UUD NRI 1945 juga menegaskan bahwa setiap orang berhak atas kebebasan meyakini kepercayaan, menyatakan pikiran dan sikap, sesuai dengan hati nuraninya. Pasal ini seolah memperjelas bahwa kebebasan beragama tidak bisa dipisahkan dari kebebasan untuk meyakini kepercayaan, menyatakan pikiran dan sikap sesuai dengan hati nuraninya, kesemua unsur itu merupakan satu-kesatuan yang tidak bisa terpisah antara satu dengan yang lainnya. Pasal ini juga memberikan penegasan bahwa selain agama, kepercayaan juga mendapatkan posisi terhormat untuk bisa diimani dan diamalkan ajarannya oleh setiap individu di Indonesia.

Namun demikian, jaminan konstitusi terhadap hak kebebasan beragama tersebut tidak lantas membuat kehidupan antar agama menjadi damai dan rukun. Dengan artian, masih banyak persoalan dan konflik yang terjadi yang dilatar-belakangi oleh perbedaan agama dan perbedaan cara penerimaan serta pemahaman terhadap agama. Salah satunya seperti yang terjadi di kota Bogor pada tanggal tanggal 22 Oktober 2015, di mana Walikota Bogor, Bima Arya, mengeluarkan surat edaran Nomor: 300/ 1321-Kesbangpol, yang isinya melarang segala tindakan atau bentuk peribadatan yang dilaksanakan penganut Syiah yang ada di Kota Bogor. Larangan ini dimaksudkan agar umat syiah tidak melakukan perayaan hari asyura yang jatuh pada tanggal 23 Oktober 2015. Alasan dikeluarkannya surat edaran ini ialah dengan mempertimbangkan terjaganya stabilitas keamanan dan ketertiban masyarakat di kota Bogor. Namun banyak pihak yang beranggapan pelarangan tersebut karena mendapat tekanan dari kelompok mayoritas keagamaan yang ada di Kota Bogor. Dalam peristiwa ini nampak jelas keberadaan pemerintah yang seharusnya bersikap netral dan memberikan perlindungan terhadap penganut agama, justru ikut mendukung tindakan perampasan terhadap hak konstitusional warga negara dalam menjalankan ibadah sesuai paham agama yang dianut dan diyakini.

Contoh lain terkait aksi kekerasan atas nama agama ialah saat terjadinya peristiwa kekerasan dan penghangusan di Kabupaten Sampang pada tanggal 29 Desember 2011 silam, di mana segerombolan massa melakukan penyerbuan dan pembakaran terhadap permukiman warga Syiah yang ada di dusun Nangkrenang desa Karang Gayam kecamatan Omben Kabupaten Sampang. Peristiwa ini kemudian menyeret pimpinan Syiah Sampang, Tajul Muluk, ke penjara dengan tuduhan melakukan tindak pidana penodaan agama.

Muncul dugaan, maraknya aksi kekerasan yang disebabkan oleh perbedaan pilihan agama ini terjadi karena ketidakjelasan konsep mengenai pembatasan yang dimaksud oleh konstitusi beserta aturan dibawahnya. Hal inilah yang kemudian menjadi celah serta menjadi alat pembenar kelompok mayoritas agama dalam menekan, merampas, dan memberangus keberadaan agama minoritas dalam suatu daerah tertentu. Pada aras ini, terdapat 2 (dua) permasalahan yang penting untuk dikaji meliputi: (a) apakah hak dan kebebasan beragama bisa dibatasi? dan (b) apakah negara berwenang dalam melakukan pembatasan terhadap hak dan kebebasan beragama? Harapannya ialah agar di masa yang akan datang, konsep pembatasan terhadap hak dan kebebasan beragama di Indonesia lebih jelas perumusan dan pengaturannya, sehingga tidak menimbulkan multi tafsir di kalangan masyarakat yang berujung pada legalnya aksi radikalisme atas nama agama.

\section{KONSEPSI PEMBATASAN HAK DAN KEBEBASAN BERAGAMA}

Ketentuan Pasal 29 Ayat (2) menegaskan bahwa "dalam menjalankan hak-hak dan 
kebebasan-kebebasannya, setiap orang harus tunduk hanya pada pembatasan-pembatasan yang ditetapkan oleh undang-undang yang tujuannya semata-mata untuk menjamin pengakuan serta penghormatan yang tepat terhadap hak-hak dan kebebasankebebasan orang lain, dan untuk memenuhi syarat-syarat yang adil dalam hal kesusilaan, ketertiban dan kesejahteraan umum dalam suatu masyarakat yang demokratis". Pasal ini mempertegas bahwa kebebasan beragama dan berkeyakinan tidak diberikan secara mutlak tanpa adanya ramburambu pembatasnya. Dengan artian, hak dan kebebasan itu bisa dibatasi manakala telah bersinggungan dengan hak orang lain.

Senafas dengan ketentuan di atas, Mill (: 52) mengemukakan gagasannya tentang "harm-principle". Gagasan ini memberikan penegasan bahwa seorang individu bebas bertindak sesuka hatinya selama dia tidak mengganggu hak orang lain dengan tindakannya tersebut. Artinya, kebebasan tersebut tidak diberikan tanpa adanya batasan dalam pelaksanaannya. Kebebasan itu terhenti manakala terdapat persinggungan dengan hak orang lain. Persinggungan tersebut niscaya membatasi kebebasan seseorang agar tidak mengganggu atau merugikan hak dan kebebasan orang lain. Secara sederhana, prinsip harm principle ini terderkripsikan dengan gambar di bawah ini:

Gambar I: Deskripsi harm principle

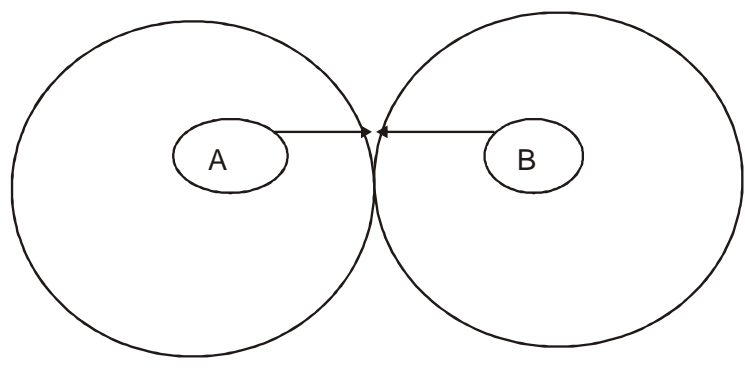

Sumber : Diambil dari buku Teologi

Konstitusi, Adam Muhshi.

Dalam kontek kebebasan beragama, harm prinsiple bermakna bahwa setiap orang bebas mengekspresikan keyakinannya selama tidak megganggu hak keyakinan orang lain. Artinya bahwa secara prinsip, setiap orang bebas untuk mengekspresikan haknya, batasnya hanyalah ketika hak itu bersinggungan dengan hak orang lain.
Selaras dengan yang disampaikan oleh Jhon Stuart Mill, Jhon Rawls memberikan pandangannya bahwa kebebasan merupakan hak yang paling utama dan semua hak yang lain merupakan pekengkapanya. Kebebasan hanya bisa dan boleh dibatasi oleh kebebasan itu sendiri, yaitu hanya jika: Pertama, hal itu akan memperkuat seluruh sistem kebebasaan yang dinikmati oleh semua orang; dan kedua, untuk memastikan bahwa kebebasan yang sama atau kebebasan dasar yang berbeda dilindungi dengan baik. Secara a contrario, tidak boleh ada pembatasan selain terhadap dua hal tersebut. Menurut teori ini, hak dan kebebasan beragama seseorang dapat dibatasi dengan tujuan untuk memastikan hak atas kebebasan beragama orang lain atau hak yang berbeda dengan orang lain dapat terpenuhi pelaksanaannya. Dengan kata lain, kebebasan beragama tersebut dapat dibatasi oleh kebebasan beragama itu sendiri, serta kebebasan dasar yang berbeda dari orang lain (Rawls, 2006: 256).

Sementara itu, Asma Jahangir sebagaimana dikutip oleh Adam Muhshi mengemukakan bahwa kebebasan beragama terdiri atas keyakinan dan manifestasi dari keyakinan tersebut. Keyakinan disebut dengan forum internum, sedangkan manifestasi keyakinan disebut dengan forum eksternum. Forum internum menyangkut kebebasan beragama yang bersifat abstrak karena ada dalam lubuk hati dan sanubari manusia. Hanya manusia yang meyakini agama-agama yang mampu mendefinisikan keyakinan sebagai bagian dari forum internum. Sedangkan forum eksternum merupakan hak kebebasan beragama yang bersifat kasat mata karena berupa prilaku keagamaan dalam bentuk ritual yang termanifestasikan dari ajaran agama dan keyakinan yang dianut oleh manusia. Bentuk dari praktik keagamaan tersebut sangat beragam tergantung bagaimana ajaran agama tersebut diterima oleh manusia (Al-Khanif: 2010: 110)

Dalam kontek ini, Asma Jahangir memberikan pandangan bahwa kebebasan yang tidak dapat dibatasi seutuhnya ialah kebebesan beragama pada forum internum. Hal ini dikarenakan bersentuhan langsung dengan keyakinan hati dan kecenderungan pikiran. Oleh karenanya tidak mungkin pikiran dapat diadili dan dibatasi. Lebih lanjut Jahangir menjelaskan bahwa pembatasan terhadap kebebasan beragama hanya dapat dilakukan pada forum eksternum, karena 
hal inilah yang sangat berpotensi bersinggungan dengan hak dan kebebasan beragama yang dimiliki oleh orang lain dan bisa menimbulkan gangguan terhadap ketertiban dan kemanan masyarakat (AlKhanif: 2010:110-111)

Bila ketentuan pembatasan kebebasan beragama seperti yang dijelaskan oleh para ahli tersebut diaplikasikan pada ranah konflik sunnisyiah yang terjadi di Sampang. Maka yang lebih mungkin dilaksanakan ialah ketentuan pembatasan terhadap forum eksternum kebebasan berama. Ini didasarkan pada fakta bahwa mayoritas penduduk di Dusun Nang-Krenang ialah penganut taat ajaran Sunni yang menjadi warisan nenekmoyangnya. Tentu, sebagaimana watak orang madura pada umumnya, yang mudah tersinggung dan mudah bereaksi ketika ada persinggungan mengenai agama, permasalahan keberadaan ajaran syiah akan mengalami pertentangan yang sangat dahsyat. Oleh karenanya, perlu adanya aturan yang jelas mengenai pembatasan yang bisa dilaksanakan pada forum eksternum.

Contoh lain ialah pembatasan terhadap tindakan kelompok keagamaan Hisbut Tahrir Indonesia (HTI), yang mengusung pemahaman radikal berupa konsep negara harus dilaksanakan secara penuh berdasarkan syariah Islam. Konsep ideologi Islam radikal seperti ini boleh saja diyakini dan diimani sebagai konsekuensi atas kebebasan setiap orang untuk beragama dan berkeyakinan. Namun, menjadi masalah ketika manifestasi keimanan tersebut ketika berada di wilayah publik di mana paham ini menganggap kurang sempurnanya keislaman seseorang jika belum menegakkan negara khilafah. Ajaran seperti ini jika didakwahkan di khalayak publik dengan alasan kebebasan menyampaikan ajaran agama justru akan membuat kekacauan dan persinggungan antar umat beragama serta tercabutnya hak orang lain untuk bebas memeluk agama tanpa hinaan dan kutukan dari agama atau kelompok keagamaan lainnya. Sehingga demi terjaminnya hak masyarakat dari persinggungan dan kekacauan akibat pengamalan manifestasi ajaran agama (kebebasan eksternum), maka selayaknya tindakan seperti ini wajib dibatasi oleh negara. Sebab jika dibiarkan secara terbuka, justru akan mengancam eksistensi Indonesia sebagai sebuah negara demokratis dan plural.

Penting diketahui, ketentuan pada forum eksternum hanya berkutat pada manifestasi dari keyakinan keagamaan, berupa menjalankan ritual agama dan sifatnya kasat mata. Oleh karenanya, pembatasan terhadap forum internum sangat mungkin dilaksanakan demi tercapainya tertib masyarakat. Tentu pembatasan tersebut tidak lantas memberangus hak untuk melakukan ibadah dan pengamalan agama, tetapi lebih kepada usaha untuk menempatkan kebebasan beribadah dan mengamalkan ajaran agama pada tempat yang aman tanpa harus mengganggu dan menyebabkan kekisruhan dengan masyarakat sekitarnya.

Berdasarkan segala penjelasan di atas, bisa dipahami bahwa keberadaan hak dan kebebasan beragama berlaku bebas pada ranah forum internum. Dengan artian bahwa kebebasan meyakini agama mutlak menjadi hak penuh setiap orang. Ini dikarenakan kebebasan ini merupakan "buah" dari hasil pemikiran dan perenungan terhadap agama mana seseorang menjatuhkan pilihan keimanan. Karenanya, pemenuhan terhadap kebebasan ini harus mutlak diberikan tanpa adanya batasan-batasan apapun termasuk dari dan oleh negara.

Pembatasan hadir manakala hak dan kebebasan beragama berinteraksi di ruang publik terkait dengan manifestasi dan implementasi ajaran agama, atau sebut saja peribadatan. Kegiatan inilah yang oleh Asma Jahangir disebut dengan kebebasan beragama di forum eksternum. Keberadaan kebebasan ini jelas akan menyebabkan persinggungan antar masing-masing manusia yang ada disekitar ruang publik itu. Karenanya, akses terhadap kebebasan ini perlu dibatasi agar tidak menimbulkan gesekan-gesekan antar masing-masing pemeluk agama.

Gesekan akan bertambah panas ketika terdapat model peribadatan atau dakwah yang terkadang "menyentil" pihak-pihak lainnya terkait masalah keimanan inti terhadap ajaran agama. Tidak jarang, gesekan tersebut pada akhirnya berujung pada perpecahan, peperangan, dan perusuhan antar masing-masing penganut agama atau antar peganut aliran dalam agama seperti yang terjadi pada kasus kekerasan terhadap aliran Ahmadiyah yang marak terjadi di berbagai daerah di Indonesia.

Dalam ajarannya, Ahmadiyah meyakini bahwa Mirza Ghulam Ahmad adalah nabi terakhir dan penerus risalah kenabian dari Nabi Muhammad SAW. Meski demikian, aliran ini tetap mengaku Islam sebagai agamanya. Ajaran Ahmadiyah tersebut langsung mendapat reaksi oleh berbagai pihak di tanah air dan berujung pada aksi kekerasan 
dan kerusuhan yang menyebabkan banyak kerugian baik kerugian harta maupun nyawa.

Dalam konteks ini, seseorang diberikan kebebasan untuk meyakini dan mengimani agama dan kepercayaan tertentu. Baik iman terhadap ajaran Ahmadiyah, Syiah, Baha'i, dan aliran lainnya. Namun, ketika berada dalam ruang publik, hendaknya membatasi diri dengan tidak melantunkan ajaranajaran kontroversial yang menyentuh langsung terhadap konsep ajaran agama atau konsep keimanan kelompok agama/aliran lainnya. Untu itu, diperlukan konsepsi pembatasan dari negara agar peperangan yang terjadi akibat perbedaan konsep dan pemahaman terhadap agama dapat dibendung bahkan bisa dihanguskan dari bumi Indonesia.

\section{KEWENANGAN NEGARA TERHADAP PEMBATASAN KEBEBASAN BERAGA- MA.}

Kebebasan beragama merupakan kebebasan konstitusional yang dimiliki oleh seluruh rakyat Indonesia. Hal ini dikarenakan hak dan kebebasan tersebut tercantum secara jelas dalam ketentuan UUD NRI 1945. Pasal 28 E Ayat (1) memberikan jaminan bahwa setiap orang yang ada di negeri ini diberikan kebebasan dalam memeluk suatu agama sesuai yang ia yakini. Ketentuan kebebasan beragama juga dijelaskan pada ketentuan Pasal 28 E Ayat (2) yang memberikan penegasan bahwa setiap orang berhak atas kebebasan meyakini kepercayaan, menyatakan pikiran dan sikap, sesuai dengan hati nuraninya. Pasal ini seolah memperjelas bahwa kebebasan beragama tidak bisa dipisahkan dari kebebasan untuk meyakini kepercayaan, menyatakan pikiran dan menyatakan sikap sesuai dengan hati nuraninya.

Selain kedua pasal diatas, jaminan terhadap kebebasan beragama juga ditemukan pada ketentuan pasal 29 Ayat (2) UUD NRI 1945 yang memberikan jaminan kepada setiap penduduk dalam rangka memeluk agama dan menjalankan ritual atau peribadatan sesuai ajaran agama yang diyakininya. Ketentuan ini memberikan penegasan bahwa negara memberikan jaminan tidak hanya terhadap hak memilih dan memeluk agama, tetapi juga jaminan terhadap kebebasan untuk menjalankan kegiatan peribadatan sesuai ajaran, anjuran, dan kewajiban yang bersumber dari ketentuan agama yang diyakini.

Kebebasan tersebut tidak diberikan secara mutlak tanpa adanya rambu-rambu pembatasnya.
UUD NRI 1945 melalui ketentuan pasal $28 \mathrm{~J}$, memberikan rambu-rambu pembatas terhadap kebebasan beragama. Ketentuan tersebut menegaskan bahwa :

"Dalam menjalankan hak dan kebebasannya, setiap orang wajib tunduk terhadap pembatasan yang ditetapkan dengan undang-undang dengan maksud semata-mata untuk menjamin pengakuan serta penghormatan atas hak dan kebebasan orang lain dan untuk memenuhi tuntutan keadilan sesuai dengan pertimbangan moral, nilai-nilai agama, keamanan, dan ketertiban umum dalam suatu masyarakat demokratis".

Berdasarkan ketentuan ini, hak yang diberikan terhadap kebebasan beragama tentunya dapat juga dibatasi dengan alasan agar tidak mengganggu dan mengurangi hak yang dimiliki orang lain, memenuhi tuntutan keadilan sesuai dengan nilai, moral, dan agama yang dianut. Juga mempertimbangkan terhadap stabilitas keamanan dan ketertiban dalam masyarakat.

Tidak berbeda dengan ketentuan pasal $28 \mathrm{~J}$ Ayat (2) UUD NRI 1945, Pasal 29 Ayat (2) Deklarasi Universal Hak Asasi Manusia (DUHAM) menegaskan bahwa:

"Dalam menjalankan hak-hak dan kebebasan-kebebasannya, setiap orang harus tunduk hanya pada pembatasanpembatasan yang ditetapkan oleh undang-undang yang tujuannya sematamata untuk menjamin pengakuan serta penghormatan yang tepat terhadap hakhak dan kebebasankebebasan orang lain, dan untuk memenuhi syarat-syarat yang adil dalam hal kesusilaan, ketertiban dan kesejahteraan umum dalam suatu masyarakat yang demokratis."

Jadi, semua ketentuan hak dan kebebasan yang diberikan dan diatur dalam DUHAM tersebut tidak diberikan secara mutlak tanpa adanya pembatasan. Kebebasan untuk beragama bisa dibatasi sepanjang kebebasan tersebut dapat mengganggu kebebasan orang lain dan dapat menimbulkan gangguan keamanan dan ketertiban dalam kehidupan berbangsa dan bermasyarakat. 
Selanjutnya, ketentuan pembatasan terhadap kebebasan beragama dapat dijumpai juga pada Undang-Undang Nomor 39 Tahun 1999 Tentang Hak Asasi Manusia (UU HAM). Ketentuan Pasal 73 UU HAM menegaskan bahwa:

"Hak dan kebebasan yang diatur dalam undang-undang ini hanya dapat dibatasi oleh dan berdasarkan undang-undang, semata-mata untuk menjamin pengakuan dan penghormatan terhadap hak asasi manusia serta kebebasan orang lain, kesusilaan, ketertiban umum, dan kepentingan bangsa"

Dalam ketentuan ini, pertimbangan yang digunakan dalam rangka pembatasan terhadap hak dan kebebasan beragama tidak sekedar karena ingin melindungi dan menghormati hak serta kebebasan orang lain, menjaga stabilitas keamanan dan ketertiban serta melestarikan nilai-nilai moral agama, tetapi pembatasan hak dan kebebasan beragama juga bisa dibatasi dengan alasan dan pertimbangan kesusilaan serta demi kepentingan bangsa.

Ketentuan pembatasan terhadap kebebasan beragama dapat juga ditemui di pasal 18 Ayat (3) Undang-Undang Nomor 12 Tahun 2005 Tentang Pengesahan Konvensi Internasional Hak-Hak Sosial dan Politik (UU ICCPR). Ketentuan tersebut menegaskan bahwa:

\section{"Kebebasan menjalankan dan menentukan agama atau kepercayaan seseorang hanya dapat dibatasi oleh ketentuan berdasarkan hukum, dan yang diperlukan untuk melindungi keamanan, ketertiban, kesehatan, atau moral masyarakat, atau hak-hak dan kebebasan mendasar orang lain.”}

Ketentuan pada undang-undang ini menambahkan bahwa pertimbangan kesehatan bisa menjadi alasan untuk membatasi hak dan kebebasan beragama. Dengan artian bahwa ketentuan pembatasan terhadap kebebasan beragama tersebut tidak hanya karena bersinggungan dengan hak dan kebebasan orang lain, mengacaukan keamanan dan ketertiban umum, tetapi bisa juga karena alasan kesehatan.

Berdasarkan beberapa ketentuan aturan perundang-undangan diatas, sekilas nampak kewenangan negara dalam upaya membatasi hak dan kebebasan beragama. Ini bisa ditelisik dari adanya ketentuan terhadap pembatasan harus tunduk pada dan berdasarkan undang-undang. Seperti yang terdapat pada ketentuan Pasal 29 Ayat (2) DUHAM, Pasal 28 J Ayat (2), Pasal 73 UU HAM, dan dengan redaksi berbeda yakni "berdasarkan ketentuan hukum pada ketentuan Pasal 18 Ayat (3) UU ICCPR. Kata hukum dan perundang-undangan tesebut mengisaratkan bahwa sebagai negara hukum, maka negara Indonesia berhak membatasi hak dan kebebasan beragama bagi rakyatnya.

Selaras dengan beberapa ketentuan di atas, Immanuel Kant memberikan pandangan terkait hak dan kebebasan manusia. Menurutnya, tiap individu akan cenderung memperjuangkan kemerdekaan yang dimilikinya dalam kebebasan dan otonomi. Namun pelaksanaan kemerdekaan seseorang mungkin dapat merugikan hak orang lain. Untuk itulah dibutuhkan hukum agar tidak terjadi pelanggaran terhadap hak orang lain sebagai akibat implementasi kebebasan seseorang. Pada aras ini, Kant berpendapat bahwa negara berwenang melakukan pembatasan terhadap kebebasan beragama dengan tujuan agar antar pemeluk agama tidak terjadi perselisihan paham dan peperangan atas nama agama (Huijbers: 1990:98).

Dengan demikian, pembatasan pelaksanaan hak atas kebebasan beragama boleh dilakukan dengan syarat pembatasannya harus dilakukan dengan ketentuan hukum. Hukum dalam hal ini difungsikan untuk membatasi kebebasan karena ketika kebebasan-kebebasan tersebut dibiarkan tidak dibatasi, maka yang akan terjadi adalah tabrakan antar masing-masing kebebasan. Negara melalui hukumnya dibutuhkan dalam upaya menghindari terjadinya tabrakan hak serta menyeimbangkan berbagai hak dan kebebasan tersebut. Berdasarkan pemaparan Immanuel Kant ini, negara berhak memberikan pembatasan hak terhadap kebebasan beragama yang tujuannya ialah untuk menjaga keseimbangan antar beberapa hak dan kebebasan, dan agar tidak terjadi benturan hak serta kebebasan khususnya dalam hal hak kebebasan beragama.

Pada dasarnya negara berwenang dalam melakukan pembatasan terhadap hak dan kebebasan beragama. Namun demikian, dalam kontek pembatasan yang dilakukan di Indonesia menemukan berbagai kendala yang salah-satunya 
berupa ketidak-jelasan konsep pembatasan itu sendiri. Dalam berbagai aturan tersebut hanya dijelaskan bahwa pembatasan dilakukan dengan alasan agar tidak mengganggu hak dan kebebasan orang lain, tidak menimbulkan kekacauan keamanan, menjaga ketertiban umum, dan kepentingan bangsa. Tetapi ketentuan tersebut tidak merumuskan secara terperinci kebebasan yang bagaimana yang dapat menimbulkan gangguan terhadap keamanan dan ketertiban, juga mengenai perbuatan spesifik seperti apa yang dapat bersinggungan dengan hak dan kebebasan orang lain. Akibatnya terdapat banyak multitafsir terhadap beberapa alasan pembatasan yang ada di aturan perundang-undangan itu. Sehingga alasan pembatasan itu justru dijadikan alasan pembenar dalam upaya menekan keberadaan kelompok minoritas keagamaan dan tidak jarang penekanan tersebut berujung pada aksi radikalisme atas nama agama.

Seperti pada kasus yang terjadi di Sampang, dalam kasus ini, para penganut syiah mendapatkan tekanan untuk menghentikan segala aktifitas keagamaannya karena bertentangan dengan paham mayoritas agama setempat dan hal itu dianggap sebagai tindakan penodaan terhadap pemurnian agama dan berpotensi mengganggu ketertiban dan keamanan dalam kehidupan bermasyarakat. Berdasarkan alasan tersebut, para tokoh masyarakat dengan berbagai cara berusaha menekan agar kaum syiah menghentikan segala ritual keagamaannya. Beragam usaha itu pun akhirnya berujung pada aksi kekerasan berupa pembakaran dan pengusiran terhadap warga syiah dari kampung halamannya (Kontras, 2012:4).

Oleh karenanya, diperlukan regulasi khusus mengenai apa yang dimaksud dengan dapat mengganggu hak dan kebebasan orang lain, perbuatan seperti apa yang berpotensi menimbulkan gangguan keamanan dan ketertiban, kebebasan seperti apa yang berpotensi bertentangan dengan nilai moral agama. Serta perumusan-perumusan alasan pembatasan yang lainnya secara terperinci agar tidak menimbulkan multi tafsir di kalangan masyarakat yang berujung pada aksi radikalisme berbasis agama seperti yang terjadi di berbagai tempat.

Penegasan terhadap konsep pembatasan hak dan kebebasan beragama sangatlah penting untuk diatur secara terperinci dalam peraturan perundang-undangan. Hal ini ditujukan untuk menghindari terjadinya multitafsir terhadap pembatasan hak dan kebebasan beragama. Multitafsir terhadap pembatasan kebebasan beragama tentu akan membahayakan kelompok keagamaan lain, utamanya kelompok minoritas agama, dalam meyakini dan menjalankan ajaran agama. Dengan alasan adanya pembatasan terhadap kebebasan beragama, bukan tidak mungkin kelompok mayoritas agama yang risih terhadap keberadaan kelompok minoritas agama lain akan melakukan berbagai tindakan untuk memberangus keberadaan kelompok minoritas agama tersebut, termasuk dengan cara kekerasan, pembantaian, penghangusan, dan tindakan radikal lain atas nama agama.

Contoh nyata bahaya ketidakjelasan konsep pembatasan terhadap kebebasan beragama ialah terjadinya aksi pembakaran terhadap komplek masjid dan pertokoan milik umat muslim di Tolikara, Papua, yang terjadi pada tanggal 27 Juli 2015 silam. Tragisnya tindakan radikal ini terjadi saat umat muslim melaksanakan shalat iedul fitri. Sekalipun terjadi pro dan kontra terhadap aksi pembakaran tersebut, tetapi tindakan pembakaran dan gangguan terhadap kebebasan seseorang untuk berkeyakinan dan beribadah merupakan tindakan yang tidak dibenarkan oleh hukum. Bila hal ini dibiarkan, ke depan akan banyak menyusul aksi-aksi radikal lain atas nama agama sebagai respon atas ketidaktegasan negara dalam mengimplementasikan prinsip kebebasan beragama dan ketidakjelasan pengaturan terhadap pembatasan kebebasan beragama.

Perlu ditekankan bahwa, kewenangan negara terhadap pembatasan hak dan kebebasan beragama seseorang hanya berlaku pada lingkup eksternum beragama. Dengan artian, masalah keimanan dan kepercayaan terhadap agama mutlak tidak dapat dibatasi oleh negara, sebagai konsekuensi logis atas dijaminnya kebebasan beragama dan berkeyakinan oleh konstitusi (hak konstitusional). Tetapi negara berwenang membatasi kebebasan beragama setiap orang pada ranah kebebasan eksternum, yang berupa pengamalan terhadap ajaran agama yang dilakukan di ranah publik.

\section{SIMPULAN}

Bedasarkan pemaparan dan penjelasan di atas, bisa disumpulkan bahwa Hak dan Kebebasan beragama dapat dibatasi pemenuhannya bila berpotensi bersinggungan dan mengganggu hak 
serta kebebasan orang lain. Ini sesuai dengan prinsip harm-principle yang dikemukakan oleh Jhon Stuart Mill serta pandangan Asma Jahangir yang mengemukakan bahwa konsep pembatasan kebebasan beragama hanya pada tataran di forum eksternum, karena di forum eksternum inilah aktifitas keagamaan dapat bersinggungan dengan hak orang lain dalam beragama dan berkeyakinan. Selanjutnya, Berdasarkan ketentuan Pasal 29 Ayat (2) DUHAM, Pasal 28 J Ayat (2) UUD NRI '45, Pasal 73 UU HAM, dan Pasal 18 Ayat (3) UU ICCPR, negara berwenang dalam membatasi hak terhadap kebebasan beragama. Hal ini kemudian diperkuat oleh pendapat Immanuel Kant

\section{DAFTAR RUJUKAN}

Fadjar, Abdul Mukhtie. 2004. Tipe Negara Hukum. Malang. Bayu Media dan Intrans Publishing.

Muhshi, Adam. 2014. Teologi Konstitusi; Hukum Hak Asasi Manusia Atas Kebebasan Beragama di Indonesia. Yogyakarta: LKiS.

Fahmi, Agung Ali. 2011. Implementasi Jaminan Hukum HAM Atas Kebebasan Beragama di Indonesia. Yogyakarta:Interpena.

Al-Khanif. 2010. Hukum dan Kebebasan Beragama di Indonesia. Yogyakarta; LakBang Mediatama.

Rawls, Jhon. 2006. Teori Keadilan (Terjemahan dari Theory Of Justice). Yogyakarta: Pustaka Pelajar. yang berpandangan bahwa dibutuhkan peran serta negara melalui aturan hukumnya untuk membatasi kebebasan beragama agar tidak bersinggungan dengan hak orang lain. Namun demikian, diperlukan adanya penegasan terperinci mengenai konsep pembatasan terhadap hak dan kebebasan beragama agar tidak menimbulkan multi tafsir di kalangan masyarakat yang nantinya dijadikan alasan pembenar dalam upaya menekan keberadaan kelompok minoritas agama seperti yang terjadi di berbagai daerah di Indonesia. Tidak jarang aksi penekanan tersebut berujung pada aksi kekerasan berbasis agama seperti kasus yang terjadi di Kabupaten Sampang, Madura.

Huijbers, Theo. 1990. Filsafat Hukum dalam Lintasan Sejarah. Yogyakarta: Kanisius. Redaksi. 2012. Laporan Investigasi dan Pemantauan Kasus Syiah Sampang. KontraS Surabaya.

Republik Indonesia. 1999. Undang-Undang Nomor 39 Tahun 1999 Tentang Hak Asasi Manusia. (Lembaran Negara Republik Indonesia Tahun 1999 Nomor 165).

Republik Indonesia. 2005. Undang-Undang Nomor 12 Tahun 2005 Tentang Pengesahan International Covenant On Civil And Political Rights (Kovenan Internasional Tentang Hak-Hak Sipil Dan Politik). (Lembaran Negara Republik Indonesia Tahun 2005 Nomor 119). 